\title{
Qualitative and semiquantitative polymerase chain reaction testing for cytomegalovirus DNA in serum allows prediction of CMV related disease in liver transplant recipients
}

\author{
P C Evans, A Soin, T G Wreghitt, G J M Alexander
}

\begin{abstract}
Aim-To identify cytomegalovirus (CMV) infection in liver transplant recipients by polymerase chain reaction (PCR) techniques and to separate the cases in which CMV related disease will occur, for whom treatment is indicated, from those in whom infection will remain innocuous.

Methods-The combination of qualitative and semiquantitative PCR of serum and urine was assessed to determine whether these assays can identify those at risk of CMV related disease and compared their performance with conventional approaches to diagnosis.
\end{abstract}

Results-Qualitative PCR of serum had superior specificity, sensitivity, and positive and negative predictive values compared with urine DEAFF (detection of early antigen fluorescent foci) and PCR of urine. All episodes of CMV related disease were associated with the presence of $\mathrm{CMV}$ DNA by PCR in serum or urine; CMV was detected before clinical onset in $70 \%$ and $60 \%$ of cases, respectively. The period over which CMV DNA could be detected was not correlated with CMV related disease. Both peak viral load and cumulative viral load estimated using a semiquantitative PCR method on serum samples positive by the qualitative method could be used to distinguish asymptomatic infection from CMV related disease with $100 \%$ specificity and sensitivity. In contrast semiquantitative PCR of urine was of little value.

Conclusions-An approach based on PCR testing with a combination of qualitative and subsequently semiquantitative serum samples would improve the diagnosis of CMV infection and aid identification of those patients at risk of CMV related disease, allowing treatment to be targeted specifically.

(f Clin Pathol 1998;51:914-921)

Keywords: cytomegalovirus; polymerase chain reaction; liver transplant

Active cytomegalovirus (CMV) infection often occurs after liver transplantation. ${ }^{1-7}$ Symptomatic infection, which usually occurs in the first few months, may be manifested as fever, malaise, arthralgia, leucopenia, thrombocytopenia, hepatitis, interstitial pneumonitis, enteritis, chorioretinitis, or disseminated disease. ${ }^{7}$
Several antiviral approaches are available. True prophylactic administration of intravenous ganciclovir can prevent CMV related disease in liver transplant recipients. ${ }^{89}$ However, ganciclovir is myelotoxic, the majority of cases do not need treatment, and prophylaxis is best targeted at those patients at increased risk. In addition, intravenous administration of ganciclovir is inconvenient, requiring prolonged hospital admission. Oral ganciclovir has recently become available and is effective in reducing the impact of CMV related disease. ${ }^{10}$ Targeting of individuals at risk of CMV related disease for pre-emptive ganciclovir treatment is an attractive alternative because patients at low risk are spared unnecessary treatment. The incidence of CMV related disease is reduced but not eradicated by this approach ${ }^{11}{ }^{12}$; a highly sensitive laboratory test is required in order that pre-emptive treatment can be given earlier, and those based on serum rather than whole blood, plasma, or buffy coat would be the most practical.

For the diagnosis of CMV infection, we have shown previously that polymerase chain reaction (PCR) detection of CMV DNA in serum is more sensitive than buffy coat DEAFF (detection of early antigen fluorescent foci) tests or CMV culture. ${ }^{13}$ Indeed, some PCR techniques may be too sensitive; thus several reports have shown that the presence of CMV DNA detected by PCR does not correlate with symptomatic infection in transplant recipients. ${ }^{14-22}$ Gerna et al reported that in 14 heart transplant recipients the presence of CMV DNA in whole blood detected by PCR alone was never associated with symptoms. ${ }^{14}$

We report the results of a prospective study in which liver transplant recipients were monitored for CMV infection using both qualitative and semiquantitative PCR for CMV DNA in serum or urine as well as conventional detection methods. Results were correlated with the presence or absence of CMV related disease to determine whether patients with or at risk of CMV related disease could be identified.

\section{Methods}

PATIENTS

Forty four liver transplant procedures in 33 adults were studied prospectively. Each was assessed twice weekly during hospital admission and monthly until six months, death or retransplantation. All were transplanted initially for chronic liver disease; none had an
Accepted for publication 29 July 1998 
underlying tumour and none had acute liver failure. Patients were selected from a larger series on the basis of survival for at least two months and a complete or near complete set of serum/urine samples, but not on the basis of CMV status or the presence/absence of CMV related disease. The study group had a median age of 49.5 years (range 17 to 63), with a male to female ratio of $1.5: 1$, and received organs from donors with a median age of 30.5 years (12 to 56$)$.

During the study period our policy was to use acyclovir as prophylaxis in all cases when the donor was CMV antibody positive but the recipient was CMV antibody negative. In patients with proven or suspected CMV related disease, intravenous ganciclovir was introduced and immunosuppression minimised. Throughout the study period triple immunosuppression with cyclosporin, prednisolone, and azathioprine was given. Episodes of acute rejection were treated with supplemental corticosteroids. CMV antibody negative recipients who received organs from CMV antibody negative donors were given CMV negative blood products.

All serum and urine samples were tested in parallel by PCR, DEAFF, and viral culture. Serology was checked every two weeks until seroconversion or a significant (fourfold) increase in the IgG titre occurred.

Clinical information was collected and analysed prospectively by two independent investigators who were blind to the virological data. We monitored the following: pyrexia, abnormal liver function test results, pneumonia, retinitis, and colitis. CMV related disease was defined as signs or symptoms of these disorders in association with confirmation of CMV infection by laboratory testing. When CMV hepatitis was suspected, liver biopsy was performed routinely and this included immunohistochemistry for the presence of CMV delayed early DNA binding protein (p52). Furthermore, symptoms were not attributed to CMV if another cause was suspected or there was concomitant rejection confirmed by liver biopsy. The post-transplant courses of these patients were thus split into episodes of CMV related disease and "CMV disease-free" episodes. Laboratory test results of samples taken during either episode were compared.

For PCR, serum and urine samples were collected. Whole blood $(5 \mathrm{ml})$ was taken and allowed to clot overnight at $4^{\circ} \mathrm{C}$; serum was collected after centrifugation at $2500 \mathrm{~g}$ for 10 minutes and stored at $-20^{\circ} \mathrm{C}$. A total of $10 \mathrm{ml}$ urine was collected in a sterile $30 \mathrm{ml}$ tube and stored at $-20^{\circ} \mathrm{C}$ before use. For cell culture and DEAFF tests, whole blood $(10 \mathrm{ml})$ was added to preservative-free heparin (250 units) and stored at $4^{\circ} \mathrm{C}$ overnight. Buffy coat samples were removed using a Pasteur pipette and tested immediately. Urine samples $(10 \mathrm{ml})$ were collected in sterile $30 \mathrm{ml}$ tubes and tested immediately.

DNA EXTRACTION FROM SERUM

DNA was extracted from $200 \mu \mathrm{l}$ serum using the Qiamp Blood Kit (Qiagen); $25 \mu$ l Qiagen protease $(19.23 \mathrm{mg} / \mathrm{ml})$ and $200 \mu \mathrm{l}$ of buffer AL (Qiagen) were mixed with $200 \mu \mathrm{l}$ serum before incubation at $70^{\circ} \mathrm{C}$ for 10 minutes and the addition of $210 \mu \mathrm{l}$ isopropanol. This mixture was applied to a silicone resin (Qiamp spin column, Qiagen) by centrifugation and washed three times with $500 \mu$ buffer AW (Qiagen). DNA was eluted into $200 \mu \mathrm{l}$ preheated $\left(70^{\circ} \mathrm{C}\right)$ water after incubation at $70^{\circ} \mathrm{C}$ for 10 minutes. This elutant was used for PCR amplification.

DNA EXTRACTION FROM URINE

The protocol reported by Yamaguchi et al was followed with modifications. ${ }^{17}$ One millilitre of urine was centrifuged at $3600 \mathrm{~g}$ for two minutes to remove cellular debris; $750 \mu$ l of urine supernatant was then mixed with $750 \mu$ l $20 \%$ PEG 6000 (Sigma) and $375 \mu 1$ of $2 \mathrm{mM}$ $\mathrm{NaCl}$ and incubated on ice at $4^{\circ} \mathrm{C}$ for 12 to 16 hours, before being centrifuged at $12000 \mathrm{~g}$ for 30 minutes. The resulting supernatant was decanted and the tubes recentrifuged $(3600 \mathrm{~g}$ for two minutes) to remove supernatant further. The pellet was resuspended in $200 \mu \mathrm{l}$ water and $50 \mu \mathrm{l}$ was subjected to PCR.

QUALITATIVE PCR

Fifty microlitres of prepared sample were added to $46 \mu$ of reaction mixture in a $0.5 \mathrm{ml}$ "amplitube" (Perkin Elmer-Cetus). PCR of a 293 bp region of CMV immediate early gene was performed using sense (5'-AAGT GAGTTCTGTCGGGTGC-3') and antisense (5'-TCCTCTGATTCTCTGGTGTCAC-3') primers.

Amplification was carried out with reaction buffer (Perkin Elmer-Cetus), $2 \mathrm{mM} \mathrm{MgCl}_{2}$ (Perkin Elmer-Cetus), $200 \mu \mathrm{M}$ each deoxynucleotide triphosphate (Pharmacia) and $1 \mu \mathrm{M}$ each primer (Pharmacia). A thermal cycler (Omnigene, Hybaid) was used to incubate this mixture at $94^{\circ} \mathrm{C}$ for five minutes, and then $55^{\circ} \mathrm{C}$ for five minutes. Tubes were then centrifuged briefly, to spin down condensation, before the addition of $2.5 \mathrm{U}$ Amplitaq (Perkin Elmer-Cetus) and $1 \mu$ l of Perfect Match Enhancer (Stratagene), and overlaid with one drop of mineral oil (Sigma). Reaction mixtures were then subjected to 30 thermal cycles $\left(72^{\circ} \mathrm{C}\right.$ for 90 seconds, $94^{\circ} \mathrm{C}$ for 30 seconds, $55^{\circ} \mathrm{C}$ for 30 seconds) and finally $72^{\circ} \mathrm{C}$ for 10 minutes.

Subsequently, $30 \mu \mathrm{l}$ of each amplified product were electrophoresed $(60 \mathrm{~V} / \mathrm{cm})$ in a $2 \%$ agarose (Sigma) gel using TAE buffer. Gels were photographed over ultraviolet light after staining with ethidium bromide $(10 \mu \mathrm{g} / \mathrm{ml})$.

Measures were taken to prevent contamination: DNA extraction, reaction mix preparation (conducted in a positive pressure laminar flow hood), and product electrophoresis were conducted in separate rooms using separate pipettes, aerosol resistant tips, and reagents. Additionally, negative (water) and positive (plasmid) controls were included in each experiment.

\section{SEMIQUANTITATIVE PCR}

Semiquantitative PCR of a single sample was performed. The quantity of product was 
measured and compared with exogenous controls. These comprised doubling dilutions of wild-type target DNA from $5 \mathrm{pg}$ to $0.15 \mathrm{pg}$, which were run alongside sample tubes and used to generate a standard curve from which concentrations of initial wild-type DNA could be calculated.

Product was quantitated using an automated fluorescence detection technique adapted from a recent report. ${ }^{23}$ PCR was conducted as described above using a fluorescein labelled sense primer. Subsequently, $3 \mathrm{ml}$ of each product was loaded onto a $6 \%$ non-denaturing polyacrylamide gel and electrophoresed using an ABI 373A automatic DNA sequencer (Genescan 1.1 software). The gel was scanned with a $40 \mathrm{~mW}$ argon ion laser at a fixed distance from the wells and subsequent fluorescence was detected by a photomultiplier tube. These data were integrated and the fluorescence intensity was presented graphically for each lane loaded. The amount of product (wild-type or deleted) was proportional to the area under the corresponding fluorescence intensity peak.

\section{DETECTION OF EARLY ANTIGEN FLUORESCENT} FOCI (DEAFF)

MRC 5 fibroblasts were grown to confluence in shell vials using $500 \mu \mathrm{l}$ minimal essential medium (MEM). Inoculation was performed by replacement of media with $500 \mu \mathrm{l}$ specimen and centrifugation (2500 $\mathrm{g}$ for 30 minutes). The specimen was then replaced with $500 \mu \mathrm{l}$ MEM and incubation at $37^{\circ} \mathrm{C}$ for 24 hours was carried out in $5 \% \mathrm{CO}_{2}$. The monolayer was then washed twice in PBS before being fixed in methanol. Monoclonal antibody to immediate early antigen (raised in mouse; Dako) was diluted 1 in 500 with PBS and $50 \mu \mathrm{l}$ was applied to the monolayer before incubation at $37^{\circ} \mathrm{C}$ for 30 minutes. The monolayer was then washed three times in PBS before dilution ( 1 in 50 with PBS) and application of fluorescein isothiocyanate conjugated antimouse antibody (raised in goat; Dako). Incubation was carried out at $37^{\circ} \mathrm{C}$ for 30 minutes before washing three times in PBS, washing once in distilled water, drying, and observation of fluorescent foci by microscopy.

ISOLATION OF CMV

CMV was isolated in MRC 5 fibroblasts which were cultured in MEM (Gibco BRL) containing $2 \%$ fetal calf serum (FCS; Gibco BRL) in tubes; $100 \mu \mathrm{l}$ specimen aliquots were added to confluent fibroblasts in $1 \mathrm{ml}$ MEM. Tubes were incubated at $37^{\circ} \mathrm{C}$ for up to three weeks, the MEM being replaced every seven days. Fibroblasts were monitored daily for evidence of CMV mediated cytopathic effect; this was observed as focal formation of rounded giant cells.

DETECTION OF CMV DELAYED EARLY ANTIGEN BY IMMUNOHISTOCHEMISTRY

Slides were dewaxed in xylene for five minutes and washed in water for five minutes before blocking of endogenous peroxidase activity with $2.5 \%$ hydrogen peroxidase ( $\mathrm{vol} / \mathrm{vol}$ ) in methanol for 10 minutes. Slides were washed again in water for six minutes before trypsinisation $(0.1 \%$ trypsin, $0.1 \% \mathrm{CaCl}(\mathrm{pH} 7.8))$ at $37^{\circ} \mathrm{C}$ for 20 minutes, a further wash in water for three minutes to stop enzyme activity, and equilibration in Tris buffered saline (TBS) for one minute. Monoclonal antibody against delayed early antigen (52; Dako) was then applied (diluted 1:500 in TBS) for 30 minutes before removal of non-specifically bound antibody by $2 \times 10$ minute washes in TBS. Goat antimouse polyclonal antibody (diluted 1:1000 in TBS) was then applied for 30 minutes before washes to remove antibody bound nonspecifically $(2 \times 10$ minutes with TBS $)$ and application of tertiary solution (streptavidin/ biotin complex conjugated to HRP (1:100 in TBS); Dako) for 30 minutes and further washes $(2 \times 10$ minutes with TBS). Development was achieved by addition of substrate/ chromagen $(0.05 \mathrm{M}$ Tris, $0.04 \mathrm{M} \mathrm{HCl}, 2.5 \%$ (vol $/ \mathrm{vol}$ ) diaminobenzidine, $0.2 \%$ hydrogen peroxide) for 10 minutes. This reaction was stopped by washing in water for 10 minutes and slides were then counterstained in Harris's haematoxylin for 15 seconds, rinsed in water, dried, and mounted.

SEROLOGICAL TESTING OF DONOR AND RECIPIENT CMV specific IgG was detected using an indirect enzyme linked immunosorbent assay (ELISA) kit (Diamedix); testing was carried out according to the manufacturer's instructions. Briefly, serum samples were applied to microtitre plate wells which had been coated with CMV antigen (whole virus proteins). Antihuman IgG antibody-alkaline phosphatase conjugate was then applied. Colour was developed after addition of substrate ( $\mathrm{p}$-nitrophenyl phosphate (PNP)) and read spectrophotometrically.

CMV specific IgM was detected using a $\mu$-capture ELISA kit (Eurogenetics); testing was carried out according to the manufacturer's instructions. Briefly, serum samples were applied to microtitre plate wells which had been coated in an anti- $\mu$ chain polyclonal antibody. All sample IgM was captured; CMV antigen (whole virus proteins) was then applied before application of CMV specific monoclonal antibody (raised in mouse) which was conjugated to horseradish peroxidase. Colour was developed after addition of substrate $\left(\mathrm{H}_{2} \mathrm{O}_{2}\right)$ and chromogen (tetramethyl benzidine (TMB)) and read spectrophotometrically.

STATISTICAL ANALYSIS

Laboratory results were compared with the presence/absence of CMV related disease by calculating the following four statistics. Sensitivity was measured as the proportion of disease episodes (or diseased patients) that tested positive. Specificity was measured as the proportion of no-disease episodes/patients that tested negative. Positive predictive value was measured as the proportion of "test positive" episodes/patients that had disease. Negative predictive value was measured as the proportion of "test negative" episodes/patients that were disease-free. Fisher's exact test was also used for comparison between groups. 
Table 1 Incidence of cytomegalovirus (CMV) infection and CMV related disease in relation to donor/recipient antibody status in 28 liver transplant recipients

\begin{tabular}{lll}
\hline & $\begin{array}{l}\text { Number with } \\
\text { CMV infection } \\
\text { (\%) }\end{array}$ & $\begin{array}{l}\text { Number of infected } \\
\text { patients with CMV } \\
\text { related disease (\%) }\end{array}$ \\
\hline CMV antibody status & $\begin{array}{l}\text { \%onor +, recipient + } \\
7 / 9(77)\end{array}$ & $4 / 7(57)$ \\
Donor +, recipient - & $9 / 9(100)$ & $7 / 9(78)$ \\
Donor -, recipient + & $3 / 6(50)$ & $2 / 3(66)$ \\
Donor -, recipient - & $0 / 4(0)$ & - \\
\hline
\end{tabular}

Donor antibody status was not always available, thus only 28 transplants could be analysed. + and - refer to the presence and absence of CMV IgG before transplantation.

\section{Results}

CMV DISEASE AFTER LIVER TRANSPLANTATION CMV infection-defined as CMV detected by PCR, DEAFF tests, viral culture of urine, or serum immunohistochemistry with or without seroconversion/antibody rise-occurred in 16 of 33 patients $(48 \%)$ and in 26 of 44 transplant procedures $(59 \%)$. CMV related disease occurred in 11 of 33 patients $(33 \%)$ and in 20 of 44 transplant procedures (46\%).

The postoperative course in these 44 liver transplant procedures was separated into episodes of CMV related disease $(n=13)$ and "CMV disease-free" episodes $(n=36)$ (five patients experienced more than one episode of CMV related disease; three patients experienced two episodes during a single transplant; and two patients experienced two episodes of CMV disease over two or more transplants). Four patients had CMV hepatitis-defined as the detection of CMV delayed early binding protein in liver following an investigational liver biopsy. In three of these, CMV infection was also confirmed by other conventional tests; all four were positive by serum PCR.

\section{ANTIBODY STATUS}

The distribution of donor/recipient CMV antibody status in relation to post-transplant CMV infection and disease after transplantation is shown in table 1 .

Transplanting a donor who was CMV antibody positive into a CMV antibody negative recipient was associated with a higher incidence of active infection than that observed for other at risk combinations $(9 / 9(100 \%) v 10 / 15$ $(66 \%)$, NS). The proportion of CMV infections that were symptomatic was also similar $(7 / 9(78 \%) v 6 / 10(60 \%)$, NS). Thus pretransplant antibody status did not identify those at risk of CMV related disease.

\section{QUALITATIVE PCR}

These results are shown in tables 2 and 3 .

Four patients were CMV antibody negative and received grafts from CMV antibody negative donors; they were not at risk of CMV infection because they also received CMV negative blood products. All samples taken from these patients (39 serum and 26 urine sample over a median 97 days (range 69 to 129 days) were CMV negative by PCR.

Qualitative PCR of serum for the detection of CMV DNA attained higher values of sensitivity, specificity, positive predictive value, and negative predictive value than urine PCR or urine DEAFF (table 3). All episodes of CMV
Table 2 Cytomegalovirus (CMV) related disease in relation to qualitative polymerase chain reaction (PCR) of serum or urine and urine DEAFF tests

\begin{tabular}{|c|c|c|c|c|c|c|}
\hline & \multicolumn{2}{|c|}{$\begin{array}{l}\text { Serum } \\
\text { PCR }\end{array}$} & \multicolumn{2}{|c|}{$\begin{array}{l}\text { Urine } \\
\text { PCR }\end{array}$} & \multicolumn{2}{|c|}{$\begin{array}{l}\text { Urine } \\
D E A F F\end{array}$} \\
\hline & + & - & + & - & + & - \\
\hline \multirow{2}{*}{$\begin{array}{l}\text { CMV related } \\
\text { disease episodes } \\
\text { CMV disease free } \\
\text { episodes }\end{array}$} & 10 & 2 & 5 & 4 & 6 & 2 \\
\hline & 3 & 30 & 6 & 26 & 5 & 24 \\
\hline
\end{tabular}

DEAFF, detection of early antigen fluorescent foci. Sensitivity, specificity, and positive and negative predictive value are shown in table 3 . Some samples were lost to analysis.

Table 3 Sensitivity, specificity, and predictive value of serum or urine polymerase chain reaction (PCR) and urine $D E A F F$ tests in relation to cytomegalovirus related disease

\begin{tabular}{lccl}
\hline & $\begin{array}{l}\text { Serum } \\
\text { PCR }\end{array}$ & $\begin{array}{l}\text { Urine } \\
\text { PCR }\end{array}$ & $\begin{array}{l}\text { Urine } \\
\text { DEAFF }\end{array}$ \\
\hline Sensitivity & $83 \%$ & $56 \%$ & $75 \%$ \\
Specificity & $91 \%$ & $81 \%$ & $83 \%$ \\
Positive predictive value & $77 \%$ & $45 \%$ & $55 \%$ \\
Negative predictive value & $94 \%$ & $87 \%$ & $92 \%$ \\
\hline
\end{tabular}

DEAFF, detection of early antigenfluorescent foci.

related disease were associated with the presence of CMV DNA in serum or urine detected by PCR. However, the presence of CMV DNA in serum or urine was not always associated with symptomatic infection.

CMV DNA was first detected by PCR in serum at a median 38 days after transplantation (range 0 to 90 days) and in urine at a median 38 days after transplantation (range 3 to 114 days). For each episode of CMV related disease, the time of first detection of CMV DNA by PCR in days post-transplant was subtracted from the time of onset of symptoms in days post-transplant and expressed as days before or after the onset of symptoms. Detection of CMV by qualitative PCR of serum occurred at a median of three days before the onset of disease (range 12 days before to 14 days after), preceding disease in seven of 10 patients with CMV disease. CMV DNA was first detected in urine by PCR at a median 12.5 days after the onset of symptoms (range 11 days before to 20 days after) but preceded symptoms in three of five patients.

The duration of the period during which CMV DNA could be detected in serum or urine by PCR during episodes of CMV infection was not correlated with CMV related disease. Serum contained CMV DNA by PCR for a median of 15 days during in symptomatic infection (range 9 to 100) and 12 days (range 3 to 53) during asymptomatic CMV infection; a patient with CMV DNA in serum by PCR for 100 days is presented as a case study later (fig 1). Urine contained CMV DNA by PCR for a similar duration in symptomatic (median 11 days (range 7-37)) and asymptomatic (median 25 days (range 14-49)) CMV infection.

\section{SEMIQUANTITATIVE PCR}

Detection of CMV DNA by qualitative PCR of serum or urine was not always associated with symptomatic infection. To determine whether specificity could be improved, all samples positive by qualitative PCR were subjected to semiquantitative PCR. This was performed along- 


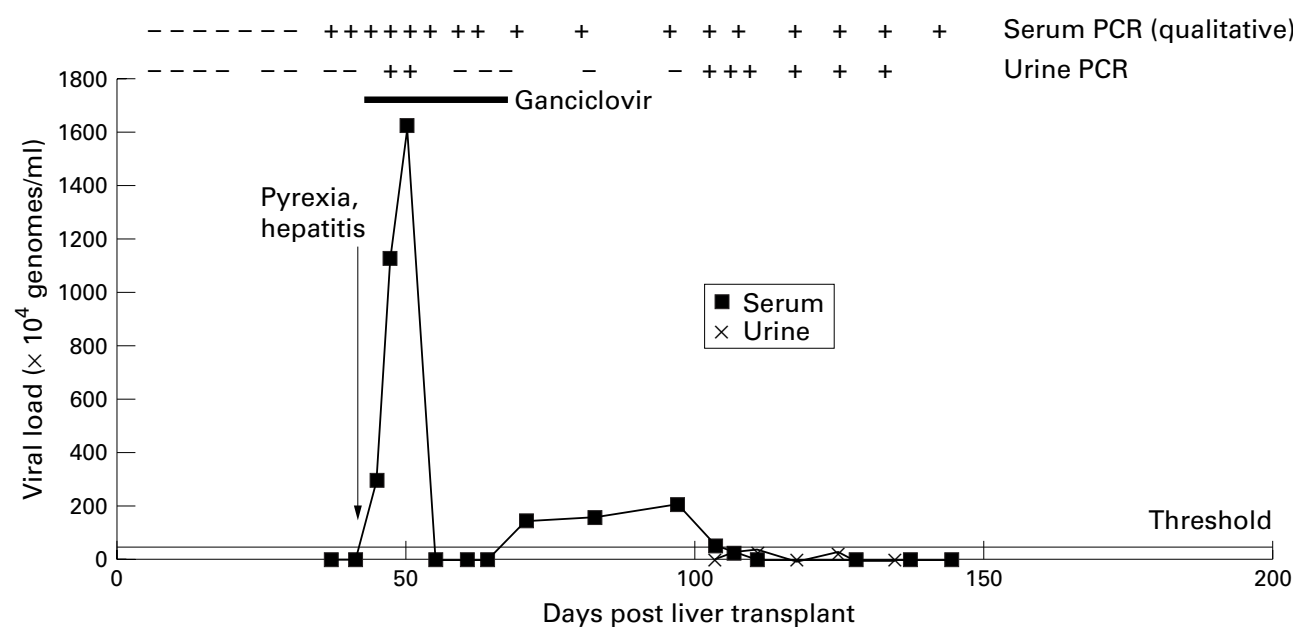

Figure 1 A liver transplant recipient mismatched for CMV status (donor + , recipient -); serum was positive initially on day 36 and remained positive for 108 days until day 144. Serum was first positive six days before the onset of CMV related disease (day 42; pyrexia, hepatitis) which corresponded with a large rise in serum viral load. The threshold of $2 \times 10^{5}$ viral genomes/ml was reached simultaneously with the onset of symptoms (day 42); serum viral load rose to a peak value on day 46. In this case CMV was not cleared after ganciclovir treatment; however, treatment did reduce viral load, which reached levels undetectable by semi-quantitative PCR on day 54 ( 11 days after treatment). Serum viral load also exceeded the threshold value between 70 days and 96 days; symptoms of acute CMV infection were not observed but the patient suffered hepatic artery thrombosis. Urine was positive at a time when the patient was well.

side exogenous plasmid controls, used to plot a standard curve to enable copy number to be inferred for each sample tested.

\section{Peak viral load}

The results generated were plotted for each patient alongside clinical details. After plotting semiquantitative serum PCR results, it was possible to draw an arbitrary threshold of 2.55 $\times 10^{5}$ genomes which divided disease-free CMV episodes of CMV infection from CMV related disease. Such a threshold could not be drawn for semiquantitative PCR of urine. The distribution of episodes of asymptomatic and symptomatic CMV infection using the threshold is given in table 4 .

Eleven episodes of symptomatic CMV infection were associated with a CMV load in serum that exceeded the threshold; the time taken to exceed this threshold and the timing of CMV related disease were compared for seven of

Table 4 Correlation of viral load with the presence or absence of cytomegalovirus (CMV) related disease during CMV infection

\begin{tabular}{lllllll}
\hline & \multicolumn{2}{l}{ Serum } & & & Urine \\
\cline { 2 - 3 } \cline { 5 - 6 } & $\begin{array}{l}2.55 \times 10^{5} \\
\text { genomes }\end{array}$ & $\begin{array}{l}>2.55 \times 10^{5} \\
\text { genomes }\end{array}$ & & $\begin{array}{l}<2.55 \times 10^{5} \\
\text { genomes }\end{array}$ & $\begin{array}{l}>2.55 \times 10^{5} \\
\text { genomes }\end{array}$ \\
\hline CMV related disease episodes & 0 & 11 & & 4 & 3 \\
Disease-free CMV episodes & 9 & 0 & & \\
$(\mathrm{p}<0.000006)$ & $(\mathrm{NS})$ & 6 \\
\hline
\end{tabular}

The peak value during each episode of CMV infection is shown; episodes of CMV infection are grouped according to presence or absence of CMV related disease. The number of peaks plotted and analysed does not equal the number of episodes of CMV infection; analysis was performed on each peak to allow vigorous examination of specificity.

Table 5 Cumulative viral load in relation to the presence or absence of cytomegalovirus $(C M V)$ disease during CMV infection

\begin{tabular}{|c|c|c|c|c|}
\hline & \multicolumn{2}{|l|}{ Serum } & \multicolumn{2}{|l|}{ Urine } \\
\hline & $\begin{array}{l}<3.8 \times 10^{6} \\
\text { genomes }\end{array}$ & $\begin{array}{l}>3.8 \times 10^{6} \\
\text { genomes }\end{array}$ & $\begin{array}{l}<3.8 \times 10^{6} \\
\text { genomes }\end{array}$ & $\begin{array}{l}>3.8 \times 10^{6} \\
\text { genomes }\end{array}$ \\
\hline CMVrelated disease & 0 & 11 & 2 & 1 \\
\hline Disease-free CMV & $\begin{array}{l}7 \\
(p=0.00003)\end{array}$ & 0 & $\begin{array}{l}5 \\
\text { (NS) }\end{array}$ & 2 \\
\hline
\end{tabular}

these episodes. Viral load in serum reached the arbitrary threshold of $2.55 \times 10^{5}$ genomes $/ \mathrm{ml}$ before or simultaneously with the onset of disease in four of seven and three of seven episodes, respectively. The threshold was exceeded before disease onset by a median four days (range 0 to 10 days).

The sensitivity, specificity, positive predictive value, and negative predictive value for semiquantitative PCR of CMV DNA in serum, in relation to the occurrence of $\mathrm{CMV}$ disease during episodes of CMV infection, were uniformly $100 \%$; semiquantitative PCR of CMV DNA in urine gave values of $43 \%, 14 \%$, $33 \%$, and $20 \%$, respectively.

\section{Cumulative viral load}

Measuring the area under plots of viral load against time enabled calculation of the cumulative viral load for each episode of CMV infection. After plotting cumulative viral load for serum PCR results, it was possible to draw an arbitrary threshold of $3.8 \times 10^{6}$ genomes which divided the disease-free CMV episodes of CMV infection from CMV related disease. Such a threshold could not be drawn for cumulative viral load for urine PCR. The distribution of episodes of asymptomatic and symptomatic CMV infection with this threshold is given in table 5 .

Sensitivity, specificity, positive predictive value, and negative predictive value of cumulative viral load in relation to CMV related disease was $100 \%$. Corresponding figures for urine were $50 \%, 71 \%, 50 \%$, and $71 \%$.

\section{CASE STUDIES}

Case studies are shown and described in figs 1 to 3. Serum and urine samples were tested throughout the post-transplant course; qualitative and semiquantitative PCR results are shown. Note that semi quantitation of CMV is illustrated using a variable y axis (either $10^{3}$ or 


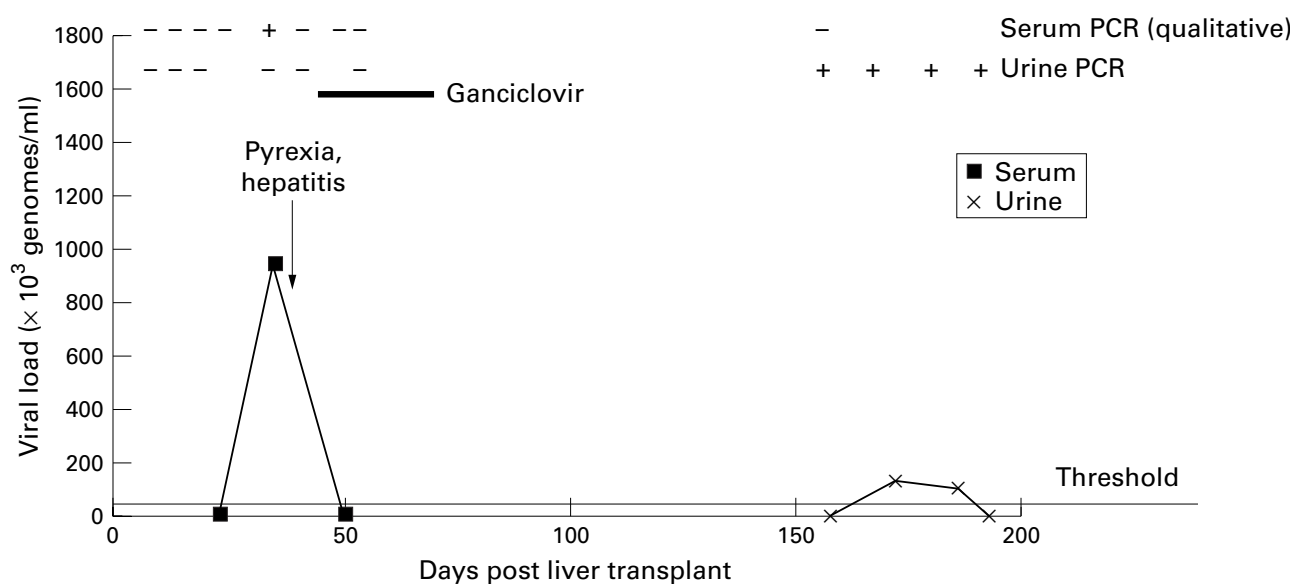

Figure 2 A liver transplant mismatched for CMV status (donor +, recipient -); serum was initially positive on day 26,12 days before CMV related disease (day 38; pyrexia, deteriorating liver function tests) which corresponded with a large rise in serum viral load. The threshold of $2 \times 10^{5}$ viral genomes $/ \mathrm{ml}$ was reached on day $29 ;$ this was nine days before the onset of symptoms and rose to a peak value on day 36. This case cleared CMV after ganciclovir treatment; CMV in urine and urinary CMV load did not correlate with disease.

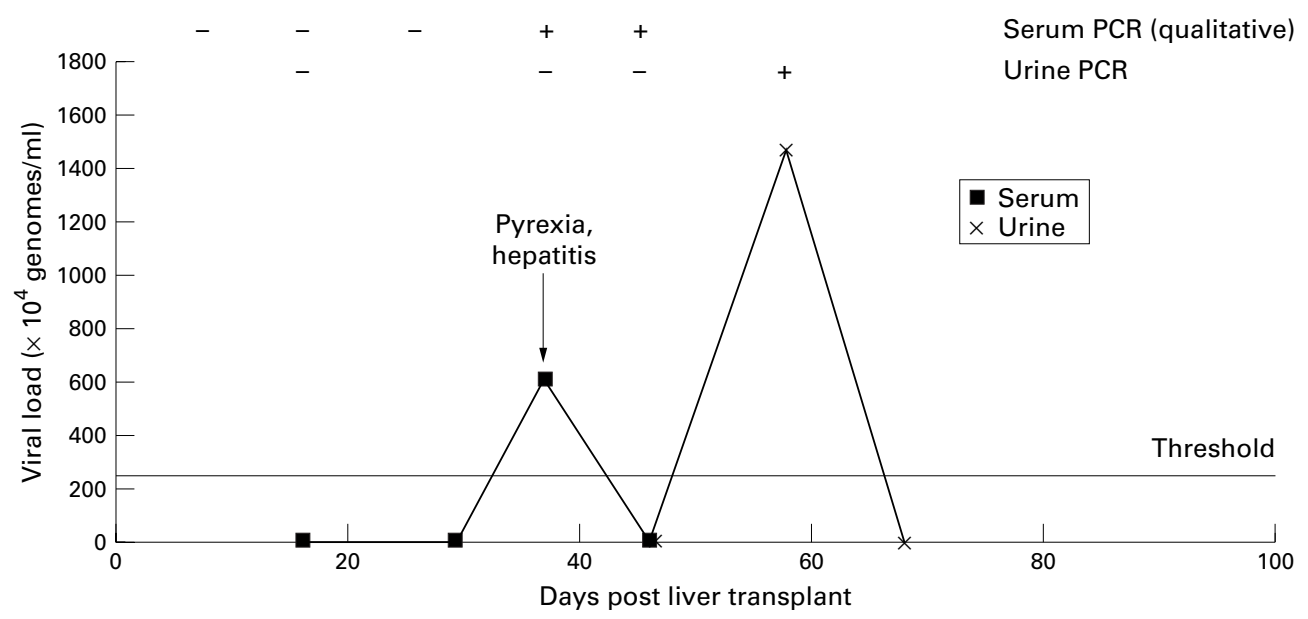

Figure 3 In this case, liver transplant recipient and donor were both CMV seropositive; serum viral load exceeded the threshold of $2 \times 10^{5}$ viral genomes/ml on day 23 ; this was 15 days before the onset of CMV related disease (day 38) which co-coincided with the peak in serum viral load. Urine was positive after serum and nine days after the onset of symptoms (day 47).

$10^{4}$ genomes $/ \mathrm{ml}$ ) according to the peak load of the case.

\section{Discussion}

We conclude that detection of CMV DNA in serum using a qualitative PCR technique was associated closely with the development of CMV infection and, in addition, that subsequent semiquantitative PCR of CMV DNA in serum allowed a threshold to be drawn that discriminated between asymptomatic and symptomatic episodes of CMV infection. Cumulative viral load cannot be useful in a clinical context since by definition it cannot be calculated until infection is complete, but may be valuable in assessing the effect of novel treatments. In contrast, however, neither qualitative nor semiquantitative PCR of CMV DNA in urine was clinically useful.

The incidence of CMV infection and disease after liver transplantation (48\% and 33\%) in this series is consistent with that reported in other centres. ${ }^{1-7}$ Mismatching for CMV serology (donor positive/recipient negative) is a risk factor for CMV infection after liver transplantation. Here, mismatched transplant recipients experienced a slightly higher incidence of CMV infection and disease compared with other at-risk combinations. Similar results have been reported by other groups. ${ }^{1-4}{ }^{24}$ Recipients exposed to CMV who are immunologically naive are at high risk of active infection as well as disease. Primary cellular immune responses to CMV are delayed owing to immunosuppression. In contrast, CMV antibody positive recipients are primed to mount specific cellular and humoral immune responses to CMV and are able to do so despite immunosuppression.

The importance of such responses in combating CMV infection has been demonstrated. $^{25} 26$ Reusser et al studied 20 recipients of marrow from CMV antibody positive donors ${ }^{26} ; 10$ recipients were able to mount cytotoxic lymphocyte (CD8+) responses when challenged in vitro with CMV infected autologous fibroblasts. None of these 10 patients developed CMV pneumonitis whereas six of 10 patients who did not mount an in vitro response died from CMV pneumonitis. Indirect evidence was provided by Fox and colleagues ${ }^{6}$ : recipient $\mathrm{CMV}$ antibody posi- 
tivity was not protective when liver transplant recipients were subjected to heavy immunosuppression (cyclosporin A and anti-thymocyte globulin).

The finding that all serum and urine samples taken from CMV antibody negative recipients whose donors were also negative were negative by PCR was an important indicator of test specificity. This result is typical of reports since the implementation of CMV negative blood product use after transplantation for naive recipients. ${ }^{27}$ PCR of whole blood correlates relatively poorly with disease ${ }^{14} 16202127-29$; the work presented here shows that detection of $\mathrm{CMV}$ in serum by qualitative and semiquantitative techniques was highly specific and $100 \%$ sensitive for CMV disease.

Two of 16 episodes of CMV disease did not test positive by serum PCR; it is possible that CMV infection was localised in the kidney (both episodes were associated with urinary CMV). It is also possible that serum was positive transiently but that this occurred in the period between sample collection; CMV may be found in serum and urine at different times (see below). Conversely, on two occasions serum was positive for CMV DNA by PCR but this was not associated with disease. In two cases, CMV was detected very early (within one week) after retransplantation for chronic rejection.

The high sensitivity and specificity of serum PCR are supported by previous reports. ${ }^{18}$ 30-33 $^{3}$ In contrast, a study of 20 liver transplant recipients by Patel et al showed that serum PCR could detect CMV disease with $100 \%$ sensitivity but specificity was only $57 \%{ }^{18}$ These investigators did not quote sensitivity with respect to naked target DNA but their test is probably more sensitive than the test used in this study because they performed Southern hybridisation after amplification. In contrast, we report $88 \%$ sensitivity and $94 \%$ specificity. $\mathrm{CMV}$ is a cell associated virus and only enters serum after lytic infection; cells infected abortedly are not detected. In addition, phagocytosed material is not detected by serum PCR.

Semiquantitation also improved the specificity and positive predictive value of the test used in this study; all serum samples with viral loads greater than an arbitrarily drawn threshold were associated with symptomatic CMV infection. This threshold was drawn after plotting of semiquantitative results; the ability to draw such a threshold suggests that semiquantitative PCR may be useful but this needs to be confirmed in a larger prospective study.

Quantitative PCR of CMV DNA has been attempted previously ${ }^{34-41}$ and successfully discriminated between asymptomatic and symptomatic CMV infection in renal $^{37}$ and liver ${ }^{38}$ transplant recipients. Most attempts have been made using buffy coat. Thus Mutimer et al reported 32 liver transplant recipients monitored by quantitative PCR of buffy coat. ${ }^{38}$ A 21 bp deleted standard was included in each tube and the initial wild-type to standard ratio was calculated after measurement of PCR products using a rapid hybridisation technique. The results were presented as CMV genomes $/ 1.5 \times$
$10^{5}$ cells; peak load varied between $8.4 \times 10^{4}$ and $1.2 \times 10^{6}$ for three patients with symptomatic infection, and between 950 and $2.8 \times 10^{5}$ for asymptomatic patients. In contrast, the results we present here do not show overlap of viral loads between symptomatic and asymptomatic; this may be because of the specificity afforded through testing serum rather than buffy coat.

Detection of CMV DNA in serum requires a more sensitive technique. Schafer et al used competitive nested PCRs to quantify the number of copies of CMV gB gene DNA per $10^{6} \beta$ globin genes present in PBL; internal controls, each differing by $3 \mathrm{bp}$ from wild-type (created by recombinant PCR) were generated for CMV and $\beta$ globin targets. ${ }^{37}$ Samples were spiked in parallel with 50 and $10^{4}$ copies, respectively, before amplification, and products were quantified by temperature gradient gel electrophoresis (TGGE). For serial peripheral blood lymphocyte samples, taken from 17 renal transplant recipients, quantitation discriminated between symptomatic and asymptomatic infection.

Rawal et al compared two semiquantitative nested PCR tests ${ }^{36}$; end point titration, visualised after agarose gel electrophoresis, and a method employing measurement of product by scintillation proximity assay (SPA) with comparison to exogenous positive controls. These two methods had comparable sensitivity and specificity. CMV DNA quantities in whole blood samples taken from six bone marrow transplant recipients experiencing active infection accurately mirrored infection and the effect of subsequent treatment but could not discriminate between asymptomatic and symptomatic infection. This lack of discrimination conflicts with the results presented here and those of Schafer ${ }^{37}$ and Mutimer ${ }^{38}$, and this may be because of "saturation" of nested PCR reactions, leading to an underestimate of viral load.

In terms of developing a diagnostic test that guides therapeutic intervention, the timing at which CMV DNA is detected by PCR is crucial. In this study, qualitative PCR detected CMV DNA in serum before disease in six of eight patients; the quantitation "threshold" was exceeded before disease in four of seven patients (and was exceeded simultaneously with disease in three of seven patients). This suggests that these PCR tests will only enable pre-emptive prophylactic treatment for a proportion of patients but will nevertheless provide useful confirmation of CMV infection for all patients. Samples were only taken twice weekly in this study and a further study of timing could be conducted by testing serum samples on a more frequent basis. Other reports have shown that PCR detects CMV DNA in whole blood before CMV disease in liver transplants, ${ }^{15} 23$ although in a series of comparable patients, CMV DNA was detected in serum by PCR at or around the onset of symptoms and disappeared with clinical resolution. ${ }^{39}$

Finally, urine testing for CMV DNA by PCR was not useful. Sensitivity, specificity, and pre- 
diction of CMV disease episodes was poor, in accordance with previous studies. ${ }^{154142}$

PCE was supported by Addenbrooke's charities.

1 Singh N, Dummer JS, Kusne S, et al. Infections with cytomegalovirus and other herpesviruses in 121 liver transplant recipients: transmission by donated organ and effect plant recipients: transmission by donated organ an

2 Stratta RJ, Schaefer MS, Markin RS, et al. Clinical patterns of cytomegalovirus disease after liver transplantation. Arch of cytomegalovirus disease

3 Sutherland S, Bracken P, Wreghitt JG, et al. Donated organ as a source of cytomegalovirus in orthotopic liver transplantation. F Med Virol 1992;37:170-3.

4 Saliba F, Gugenheim D, Samuel D, et al. Incidence of cytomegalovirus infection and effects of cytomegalovirus immune globulin prophylaxis after orthotopic liver transplantation. Transplant Proc 1987;19:4081-2.

5 Converse P, Hess A, Tutschka P, et al. Effect of cyclosporine on the response of normal human lymphocytes to cytomegalovirus in vitro. Infect Immun 1983;41:1226-33.

6 Fox AS, Tolpin MD, Baker AL, et al. Seropositivity in liver transplant recipients as a predictor of cytomegalovirus disease. F Infect Dis 1988;157:383-5.

7 Stratta RJ, Schaeffer MS, Markin RS, et al. Cytomegalovirus infection and disease after liver transplantation: an infection and disease after liver

8 Winston DJ, Wirin D, Shaked A, et al. Randomised comparison of ganciclovir and high-dose acyclovir for comparison of ganciclovir and high-dose acyclovir for long-term cytomegalovirus prophylar
recipients. Lancet 1995;346:69-74.

9 Martin M, Manez R, Linden P, et al. A prospective randomized trial comparing sequential ganciclovir-high dose acyclovir to high dose acyclovir for prevention of cytomegalovirus disease in adult liver transplant recipients. Transplantation 1994;58:779-85.

10 Gane E, Saliba F, Valdecasas GJC, et al. Randomised trial of efficacy and safety of oral ganciclovir in the prevention of cytomegalovirus disease in liver transplant recipients. Lancet 1997;350:1729-33.

11 Winston DJ. Prevention of cytomegalovirus disease in transplant recipients. Lancet 1995;346:1380-1.

12 Singh N, Yu VL, Mieles L, et al. High-dose acyclovir compared with short-course preemptive ganciclovir therapy to prevent cytomegalovirus disease in liver therapy to prevent cytomegalovirus disease in liver 1994;120:375-81.

13 Evans PC, Gray J, Wreghitt TG, et al. Optimisation of the polymerase chain reaction (PCR) and dot-blot hybridisation for detecting cytomegalovirus DNA in urine: comparison with detection of early antigen fluorescent foc (DEAFF) and culture. F Virol Methods 1998;73:41-52.

14 Gerna G, Zipeto D, Parea M, et al. Monitoring of human cytomegalovirus infections and ganciclovir treatment in heart transplant recipients by determination of viraemia, antigenaemia and DNAemia. F Infect Dis 1991;164:48898.

15 Kidd IM, Fox JC, Pillay D, et al. Provision of prognostic information in immunocompromised patients by routine application of the polymerase chain reaction for cytomegalovirus. Transplantation 1993;56:867-71.

16 Delgado R, Lumbreras C, Alba C, et al. Low predictive value of polymerase chain reaction for diagnosis of cytomegalovirus disease in liver transplant recipients. $\mathcal{f}$ Clin Microbiol 1992;30:1876-8.

17 Yamaguchi Y, Hironaka T, Kajiwara M, et al. Increased sensitivity for detection of human cytomegalovirus in urine by sitivity for detection of human cytomegalovirus in urine by
removal of inhibitors for the polymerase chain reaction. $\mathscr{F}$ removal of inhibitors for the poly

18 Patel R, Smith TE, Espy M, et al. Detection of cytomegalovirus DNA in sera of liver transplant recipients. $\mathcal{F}$ Clin Microbiol 1994;32:1431-4

19 Zipeto D, Revello MG, Silini E, et al. Development and clinical significance of a diagnostic assay based on the polymerase chain reaction for detection of human cytomegalovirus DNA in blood samples from immunocompromised patients. F Clin Microbiol 1992;30:527-30.

$20 \mathrm{Xu} \mathrm{W}$, Sundqvist VA, Brytting M, et al. Diagnosis of cytomegalovirus infections using polymerase chain reaction, virus isolation and serology. Scand 7 Infect Dis 1993; 25:311-16.
21 Einsele H, Ehninger G, Steidle M, et al. Polymerase chain reaction to evaluate antiviral therapy for cytomegalovirus disease. Lancet 1991,338:1170-2.

22 Zaia JA, Forman SJ, Gallagher E, et al. Prolonged human cytomegalovirus viraemia following bone marrow transplantation. Transplantation 1984;37:315-17.

23 Karet FE, Charnock-Jones S, Harrison-Woolrych ML, et al. Quantitation of mRNA in human tissue using fluorescent nested reverse transcriptase polyr

24 Schmidt CA, Oettle $\mathrm{H}$, Neuhaus $\mathrm{P}$, et al. Demonstration of cytomegalovirus by polymerase chain reaction after liver transplantation. Transplantation 1993;56:872-4.

25 Quinnan G, Kirmani N, Rook A, et al. HLA restricted T-lymphocyte and non-T lymphocyte cytotoxic responses correlate with recovery from cytomegalovirus infection in bone marrow transplant recipients. $N$ Engl $f \mathrm{Med}$ 1982;307:7-13.

26 Reusser P, Riddell SR, Meyers JD, et al. Cytotoxic T-lymphocyte response to cytomegalovirus after human allogeneic bone marrow transplantation: pattern of recovery and correlation with cytomegalovirus infection and disease. Blood 1991;78:1373-80.

27 Bowden RA, Sayers M, Flournoy N, et al. Cytomegalovirus immune globulin and CMV seronegative blood products to prevent primary cytomegalovirus infection after marrow transplantation. N Engl F Med 1986;314:1006-10.

28 Prosch S, Kimel V, Dawydowa I, et al. Monitoring of patients for cytomegalovirus after organ transplantation by centrifugation culture and PCR. F Med Virol 1992;38:24651.

29 Drouet E, Michelson S, Denoyel G, et al. Polymerase chain reaction detection of humans cytomegalovirus in over 2000 blood specimens correlated with virus isolation and related to urinary virus excretion. F Virol Methods 1993;45:259-76.

30 Ishigaki S, Takeda M, Kura T, et al. Cytomegalovirus DNA in the sera of patients with cytomegalovirus pneumonia. $\mathrm{Br}$ in the sera of patients with cyt
f Haematol 1991;79:198-204.

31 Brytting M, Xu W, Wahren B, et al. Cytomegalovirus DNA detection in sera from patients with active cytomegalovirus infections. F Clin Microbiol 1992;30:1937-41.

32 Spector SA, Merrill R, Wolf D, et al. Detection of human cytomegalovirus in plasma of AIDS patients during acute visceral disease by DNA amplification. 7 Clin Microbiol 1992;30:2359-65.

33 Spector SA, Wolf DG. Early diagnosis of human cytomegalovirus disease in transplant recipients by DNA amplification in plasma. Transplantation 1993;56:330-4

34 Kulski JK. Quantitation of human cytomegalovirus DNA in leukocytes by end-point titration and duplex polymerase chain reaction. $\mathcal{F}$ Virol Methods 1994;49:195-208.

35 Gerna G, Furione M, Baldanti F, et al. Comparative quantitation of cytomegalovirus DNA in blood leukocytes and plasma of transplant and AIDS patients. F Clin Microbiol 1994;32:2709-17.

36 Rawal BK, Booth JC, Fernando S, et al. Quantification of cytomegalovirus DNA in blood specimens from bone marrow transplant recipients by the polymerase chain reaction. F Virol Methods 1994;47:189-202.

37 Schafer P, Braun RW, Mohring K, et al. Quantitative determination of human cytomegalovirus target sequences in peripheral blood leukocytes by nested polymerase chain reaction and temperature gradient gel electrophoresis. $\mathcal{F}$ Gen Virol 1993;74:2699-707.

38 Mutimer D, Matyi-Toth A, Elias E, et al. Quantitation of cytomegalovirus in the blood of liver transplant recipients. Hepatology 1994;20:A134.

39 Mutimer D, Matyi-Toth A, Shaw J, et al. Patterns of viraemia in liver transplant recipients with symptomatic cytomegalovirus infection. Transplantation 1997;63:68-73.

40 Nyberg G, Bergstrom T, Blohme H, et al. Clinical evaluation in organ transplant recipients of a polymerase chain in organ transplant recipients of a polymerase chain serum. Transplant Int 1994;7:428-33.

41 Demmler GJ, Buffone GJ, Schimbor CM, et al. Detection of cytomegalovirus in urine from newborns by using polymerse chain reaction DNA amplification. F Infect Dis 1988; 158:1177-84.

42 Miller MJ, Bovey S, Pado K, et al. Application of PCR to multiple specimen types for diagnosis of cytomegalovirus infection: comparison with cell culture and shell vial assay. f Clin Microbiol 1994;32:5-10. 